Check for updates

Department of Health Policy, London School of Economics, London, UK

C.Wenham@lse.ac.uk

Cite this as: BMJ2021;372:n303

http://dx.doi.org/10.1136/bmj.n303

Published: 04 February 2021

\section{What went wrong in the global governance of covid-19?}

\author{
Plenty, according to the latest independent panel report \\ Clare Wenham assistant professor of global health policy
}

The mandate of the Independent Panel for Pandemic Preparedness and Response is to "provide an evidence-based path for the future, grounded in lessons of the present and the past to ensure countries and global institutions, including specifically WHO, effectively address health threats." ${ }^{1}$ These lessons are starting to emerge with the publication of the panel's second progress report. ${ }^{2}$ Unsurprisingly, the report touches several key problems in the global governance of covid-19: WHO's position, structure, and lack of financing; excessive focus on metrics to the detriment of political analysis; a lack of coordinated and sufficient financing for pandemic preparedness and response; global vaccine inequities; and the role of the broader global health architecture.

Almost every section of the report points to the extent to which politics has driven the trajectory of the pandemic in different locations-establishing that the policies chosen by governments reflect deeper political agendas and that the tension between the economy and public heath is a false dichotomy. Those governments willing to take the political and economic hit of harsh restrictions early in 2020 are now benefiting from freedom from population restrictions, and in the case of South Korea and China, flourishing economies.

Trying to appease both public health demands and the libertarian views of the free market has led not only to astronomical death tolls, such as in the US, UK, and Brazil, but to flailing economies. Halfway compromises do not work in response to pandemics and have just dragged out the pandemic for all. Frustratingly, for those of us who research the politics of global health security, this was entirely foreseen. ${ }^{34}$

The panel's suggestion that protocols within the International Health Regulations (IHR)-WHO's legal framework for preventing, detecting, and responding to emerging pathogens-are from an analogue era and need to be digitalised are misconstrued. It was through digital systems such as HealthMap, ProMED-Mail, and WHO's Global Outbreak and Alert Response Network that the world first came to know about Ebola, Zika, and SARS-CoV-2. All these mechanisms are permitted under article 9 of the IHR. ${ }^{5}$

\section{Act on the lessons}

The panel identifies 12 previous commissions and panels that made similar recommendations on how to improve global health security. The lessons in this second progress report repeat much of what was said in the other reviews. However, real progress can occur only if the effort and people power currently devoted to convening new panels is diverted instead to implementing their recommendations. We need to move on from reviews and prioritise action to fix the identified weaknesses.

The overwhelming subtext to the independent panel's report is that the system we have established for global health security cannot respond adequately to a health emergency. Global health security remains too focused on prevention and detection-improving surveillance, laboratory capacity, and the resilience of health systems-with too little attention paid to a managed response. Going forward, the mechanisms for managing health emergencies must rapidly scale up the response element of pandemic preparedness plans, including learning from clear evidence. ${ }^{6}$

However, given the politicisation of responses globally, any efforts to develop a standardised response to health emergencies will have to overcome serious challenges to secure agreement among all member states. Full agreement and adherence are unlikely without WHO building the trust of member states and gaining greater authority in global disease governance. $^{7}$

An alternative proposal from the EU is to create political buy-in through a new treaty for pandemic preparedness. ${ }^{8}$ However, treaties work only if they are ratified by states. The Framework Convention for Tobacco Control, for example, is often hailed a success but has not been ratified by several countries, showing the challenges inherent in a treaty. ${ }^{9}$

The UK government's leadership of $\mathrm{G}_{7}$ is set to champion global health security, including review and reform of WHO. ${ }^{10}$ As the independent panel highlights, global health security has to start with an empowered WHO with the mandate, authority, and financing to execute the public health delivery expected of it. To do this, WHO must confront the geopolitical tensions it has experienced, such as between the US and China, to reassert its leadership and hold governments to account for their flagrant departure from WHO guidance for pandemic preparedness and response. This includes considering whether China could have done more in the early stages of the pandemic, which a WHO panel is currently investigating. ${ }^{11}$ Would governments have acted differently had they known about the pathogen sooner?

We need to make sure that accountability is not just focused on China but on the many states that delayed their preparedness and response efforts. The panel highlights that "it is clear that the volume of infections in the early period of the epidemic in all countries was higher than reported." ${ }^{2}$ We need a targeted review that names and shames governments, rather than obscuring them with generalisations. I look forward to bolder reports from the independent 
panel that consider not only the economic and social effect of the pandemic but the failure of Western governments too.

Competing interests: I have read and understood BMJ policy on declaration of interests and have no relevant interests to declare.

Provenance and peer review: Commissioned; not externally peer reviewed.

1 Independent Panel of Pandemic Preparedness and Response. About the independent panel 2020. https://theindependentpanel.org/about-the-independent-panel/

2 Independent Panel of Pandemic Preparedness and Response. Second report on progress. 2021.

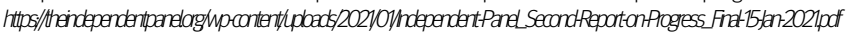

3 Rushton S. Global health security: security for whom? Security from what? Polit Stud 2011;59:779-96. doi: 10.1111/j.1467-9248.2011.00919.x.

4 Brim B, Wenham C. Pandemic Emergency Financing Facility: struggling to deliver on its innovative promise. BMJ 2019;367:15719. doi: 10.1136/bmj.l5719 pmid: 31597630

5 Wenham C. Digitalizing disease surveillance: the global safety net. Glob Health Gov 2016;10:124-37.

6 Han E, Tan MMJ, Turk E, etal. Lessons learnt from easing COVID-19 restrictions: an analysis of countries and regions in Asia Pacific and Europe. Lancet 2020;396:1525-34. doi: 10.1016/S0140-6736(20)32007-9 pmid: 32979936

7 Global Preparedness Monitoring Board. A world in disorder. 2020 https://apps.who.int/gpmb/annual_report.htm

8 European Council. Press release by President Charles Michel on an international treaty on pandemics. 3 Dec 2020

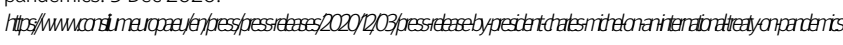

9 Collin J, Lee K, Bissell K. The framework convention on tobacco control: the politics of global health governance. Third World Q2002;23:265-82. doi: 10.1080/01436590220126630

10 UK Government. Prime minister's speech to United Nations General Assembly: 26 September 2020.

https://unw.gov.uk/govemment/speeches/prime-ministers-speech-to-un-general-assembly-26-september-2020

11 Crossley G. WHO says team in Wuhan to visit labs, markets and hospitals. Japan Today 2021 Jan

https//Japantoday.com/category/world/update-7-who-says-team-in-wuhan-to-visit-labs-markets-and-hospitals

This article is made freely available for use in accordance with BMJ's website terms and conditions for the duration of the covid-19 pandemic or until otherwise determined by BMJ. You may use, download and print the article for any lawful, non-commercial purpose (including text and data mining) provided that all copyright notices and trade marks are retained. 